\title{
Ryanodine Receptor 1
}

National Cancer Institute

\section{Source}

National Cancer Institute. Ryanodine Receptor 1. NCI Thesaurus. Code C150313.

Ryanodine receptor 1 (5038 aa, $\sim 565 \mathrm{kDa}$ ) is encoded by the human RYR1 gene. This protein is involved in the transport of calcium ions from the sarcoplasmic reticulum and neurons. 